\title{
A RELAÇÃO DO MATERIALISMO HISTÓRICO COM A PSICANÁLISE E SUAS IMPLICAÇÕES PARA A AD
}

Maria da Conceição Fonseca Silva*

"não se pode deixar jamais um erro dormir impunemente em paz, pois esse será um meio seguro para que ele pendure; é preciso discernir o que falha não por pretender com isso se amparar definitivamente o verdadeiro(!), mas para tentar avançar tanto quanto se possa em direçäo d̀ justiça".

(Michel Pêcheux)

\section{Considerações iniciais}

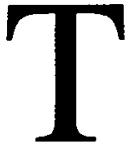

ento fazer algumas reflexões que dizem respeito à relação do materialismo histórico com a psicanálise e suas implicações para a Análise do Discurso de linha francesa (doravante AD).

Ao finalizar o artigo no qual fala sobre as três épocas da AD, Pêcheux (1983) faz uma série de interrogaçōes, muitas das quais apontam para uma reavaliação no tocante ao atravessamento da teoria psicanalítica da subjetividade na AD:

* Professora de Lingüística do Departamento de Estudos Lingüisticos e Literários da Universidade Estadual do Sudoeste da Bahia. Doutoranda em Lingüística - UNICAMP. 
"Como separar, nisso que continuamos a chamar 'o sujeito da enunciação', o registro funcional do 'ego-eu' estrategista assujeitado (o sujeito ativo intencional teorizado pela fenomenologia) e a emergência de uma posição sujeito? Que relação paradoxal essa emergência mantém com o obstáculo, a irrupção imprevista de um discurso-outro, a falha no controle? $O$ sujeito seria aquele que surge por instantes, lá onde o 'egoeu' vacila? Como inscrever as conseqüências de uma tal interrogação nos procedimentos concretos de análise?" (p.317).

É sabido que, através da ampliação da noção de interpelação althusseriana, Pêcheux (1975) faz corresponder conceitos de Althusser, Freud e Lacan para explicar o que vem a ser sujeito do discurso. $O$ sujeito, explicado pela aproximação do "Outro" (que confirma a alienação do sujeito à Ordem) de Lacan ao "Sujeito" (enquanto absoluto e universal e que está sempre "jáarân" para manter todos os seus lugares designados nas sociedades de classe) de Althusser, é assujeitado e, para agir, tem a ilusão de ser livre, mesmo quando se submete. É um efeito das FDs e das FIs que the são exteriores ${ }^{1}$ e assim ele (sujeito) se perde no processo de assujeitamento.

Como já apontei em Silva (1999), esse tratamento dado ao sujeito por Pêcheux (1975), no entanto, abre a perspectiva para vários questionamentos, principalmente, no tocante à noção althusseriana de interpelação que faz intervir os conceitos advindos de Lacan.

Quando o autor diz que "a questão da 'supremacia absoluta do Simbólico' traz consigo uma filosofia e uma epistemologia lacaniana cujos interesses devem ser confrontados com o do materialismo histórico", ${ }^{2}$ tenta, na realidade, superar as noções filosóficas que visam a fazer do sujeito um ser livre e determinado, e, para tanto, confere à subjetividade uma dimensão ideológica e psicanalítica ao mesmo tempo. Acontece, porém, que o "Outro" de Lacan tem um alcance que não se encontra em Althusser e nem mesmo na retomada feita por Pêcheux (1975), como tentarei demonstrar a seguir.

1 Um exterior que permanece excluído do seu campo de visão pelo que Pêcheux chama de esquecimento $n^{\circ} 1$.

2 Pêcheux, 1975, p. 139 
SILVA, M. da C. F. A relação do materialismo histórico...

\section{Althusser: Marxismo e Psicanálise}

Retomarei algumas questões da teoria Althusseriana de ideologia, já que é inspirado em Althusser para quem a subjetividade é vista sob a perspectiva marxista e psicanálitica que Pêcheux (1975) tenta articular as estruturas funcionamentos: ideologia e inconsciente.

Na tentativa de compreender melhor essa questão, faço, primeiramente, referência a Evangelista (1984) que apresenta um minucioso panorama para introduzir a publicação dos textos de Althusser: "Freud e Lacan" (64) e "Marx e Freud" (76), nos quais estão demonstradas as primeiras tentativas de aproximação do Materialismo e da Psicanálise.

Segundo esse autor, no momento em que o marxismo se achava ameaçado, a intervenção filosófica de Althusser foi decisiva na cena francesa para promover o que se tornou conhecido como um (re)começo do Materialismo Dialético, marcado por estratégias que abrangem dois grandes momentos. No primeiro, que culmina em 1965, a cientificidade do Materialismo Histórico, que se achava encoberto por ideologias, mostrou-se de modo vigoroso, e foi decisivo o recurso à categoria bachelardiana de ruptura, assumida por Althusser sob a forma do conceito de corte epistemológico. Assim, nessa primeira fase a luta de classes foi relegada a segundo plano, pois a Filosofia, ao assimilar-se à Epistemologia e ao definir-se como Teoria das práticas teóricas, concentrou-se na oposição Ciência X Ideologia. No segundo momento, por sua vez, que tem início em 1967 e auge em 1974, a Filosofia é redefinida como Política na teoria. Em consequiência, a luta de classes, que havia sido relegada no primeiro momento, retoma scus direitos.

O fato marcante é que, em ambos os momentos dessas estratégias que provocou o (re)começo do Materialismo Histórico, a intervenção de Althusser é decisiva quanto às possibilidades de aproximação do Marxismo e Psicanálise. E sobre isso diz Evangelista:

\footnotetext{
"Nessa estratégia e nesse confronto, "Freud e Lacan" (1964) bem como "Marx e Freud" (1976), (...) são duas táticas essenciais, adotadas, cada uma delas, em cada um dos referidos momentos. A leitura de ambos permite, portanto, na medida em que abrange esses dois momentos, uma forma de acesso completa, embora unilateral, à démarche althusseriana". ${ }^{3}$
} 
De acordo com a citação acima, esses dois artigos indicam dois momentos distintos e duas diferentes definições de Filosofia. Um maior esclarecimento sobre esses dois momentos é relevante para que possamos compreender melhor essas duas definições.

Esse autor salienta que o estreito relacionamento entre o projeto althusseriano e a Psicanálise remete ao conceito de sobredeterminação (cuja definição está diretamente ligada à descrição do inconsciente, conceito principal da descoberta freudiana, e que Althusser toma emprestado para o desenvolvimento do seu projeto) e ao conceito de causalidade (que está, de certa forma, ligado ao conceito de estrutura).

No projeto althusseriano, o conceito de sobredeterminaf̧ão se constitui no instrumento através do qual ele poderia elaborar a diferença entre a dialética marxista e a hegeliana, principalmente, por causa de uma das suas estruturas denominada contradição - tida como o motor de toda dialética e que exprime o tipo de causalidade da dialética pensada por Marx e pela tradição marxista. E a qualidade dessa contradição em jogo na dialética marxista só pode ser apreendida através do conceito que lhe forneça o 'traço mais profundo'. Para isso, Althusser busca a Lingüística e a Psicanálise, precisamente Lacan, e propõe o conceito de sobredeterminação, o que resulta a contradição sobredeterminada. Enfim, "o traço mais profundo da dialética marxista" é tomado do Doutor Jacques Marie Emile Lacan que, além de ter sido condenado pelos 'marxista 48', foi, em 1963, excomungado pela Sociedade Francesa de Psicanálise.

O primeiro texto, "Freud e Lacan", é, assim, antes de tudo, um texto de luta téorica. Nele, Althusser se define em relação a um texto de 1949 'Auro-critique: Ia psychanalyse, une idéologie reationnaire': e dirige-se, principalmente, aos 'marxistas que haviam cometido o erro $\mathrm{em} 49$ de jogar fora a Psicanálise. Lacan não era, como assinala Evangelista, ${ }^{4}$ desconhecido dos 'marxista 48'; ao contrário, era atacado, e, por isso, era preciso resgatar, mostrar e defender o caráter científico da Psicanálise em geral e do trabalho de Lacan em particular. Isto não significa que ele estivesse querendo fundar o discurso da Psicanálise e o discurso de Lacan. Em outras palavras, através desse texto, Althusser fez seu trabalho e abriu caminho para que Lacan fosse ouvido: "Freud e Lacan' é antes de qualquer outra coisa, um ato político, e como tal deve ser avaliado".

Nesse primeiro momento, Althusser recusando o dogmatismo stalinista, base do Materialismo Dialético tradicional, define Filosofia como teoria da prática teórica. Fala das práticas teóricas como ciências que se apropriam da prática real dos homens existentes transformando-as em ciências com objeto próprio: $a$ luta de classes em, $O$ Capital, de Marx, e o inconsciente, em a Interpretação dos 
Sonhos, de Freud. Elaborar a teoria dessas práticas teóricas seria o objeto da Filosofia. Esta concepção tem como pressupostos filosóficos Kant, Bachelard, Engels, mas, principalmente, Stalin, no que diz respeito à oposição Ciência X Ideologia. O problema apresentado de imediato é que essa definição de Filosofia supõe uma Teoria geral única que se imporia a todas as ciências.

Este empreendimento de uma Teoria geral, superteoria, comportou um alto risco, pois chegou, conforme Evangelista, "a sugerir, depois de Freud e Lacan", por exemplo, que seria possível uma fusão entre a tópica marxista e a freudiana, na figura de um discurso de sobredeterminação, que seria uma Teoria Geral da Ciência, enquanto teoria geral dos discursos.

Acontece, porém, que, no segundo momento, surge um novo Althusser. A partir de 1967, no prefácio à edição italiana de "Lire le Capital" anuncia-se um movimento geral de autocrítica, definida claramente em "Elementos de Autocrítica", em 1974. Nesse movimento há recusa da noção de Filosofia sobre a qual foram escritos "Freud e Lacan", "Pour Marx" e "Lire le Capital". A filosofia passa a ser definida como uma prática política na teoria, ou seja, uma representação da luta de classes na teoria. Assim, "Marx e Freud" é um texto que surge para mostrar como não se pode separar teoria da vida, através do conflito e da irracionalidade, como nos mostra Evangelista:

\footnotetext{
"Se a Psicanálise é 'irracional', porque supõe o 'inconsciente' como condição de sua produção, e esse inconsciente não é a Razão, então o marxismo, igualmente, será 'irracional', porque este supõe a luta de classes, e esta não é a Razão, mas, sim, o conflito das razões"?
}

Neste sentido, esse artigo corrige os desvios do primeiro momento, demonstrando que não há a Teoria, distinguindo com rigor o objeto de Freud do de Marx, ao reconhecer a singularidade de cada um dos objetos do conhecimento:

\footnotetext{
"Althusser restabelece a distância adequada: Marx e Freud, o mesmo combate contra a noção ideológica do sujeito, mas em dois campos radicalmente distintos, porque duas ciências distintas". 8
} 
Se, no primeiro momento, houve a tentativa de fundir o Materialismo Histórico e a Psicanálise, no discurso da sobredeterminação; no segundo, ao contrário, as duas ciências são colocadas como formas distintas de apropriação do real e não têm e nem podem ter o mesmo objeto de conhecimento. Mas o problema persiste: como articular essas duas ciências?

Em Althusser, a possibilidade de aproximação do Materialismo Histórico com a Psicanálise está além dos dois artigos mencionados. Essa tentativa encontra-se também em "Aparelhos Ideológicos do Estado" (1970). O autor propõe um esquemático esboço de um projeto de uma teoria da ideologia em geral, e não de uma teoria das ideologias particulares que exprimem posições de classe, apontando aí a distinção para dois planos: o da estrutura da ideologia e o das diversas modalizações no interior de uma formação dada.

Ele diz ser necessário empreender uma teoria das ideologias a partir dessa dupla relação. Acrescenta que, se pode apresentar um projeto de uma teoria em geral $e$ se esta teoria se constitui em um dos elementos do qual dependem as teorias das ideologias, isso implica que "a ideologia não tem história" (p.82-3).

Retomando formalmente essa expressão de "A ideologia alemã", em que "a ideologia não tem história, uma vez que sua história está fora dela, lá onde está a única história, a dos individuos concretos etc.," (p.83), Althusser rompe com essa tese positivista-historicista e sustenta que, num sentido positivo, a ideologia em geral não tem história, já que tem uma estrutura e um funcionamento tais que fazem dela uma realidade não-histórica. $\mathrm{O}$ autor eleva a ideologia ao estatuto teórico, comparando sua proposição à proposição de Freud de que o inconsciente é eterno, e afirma:

"Se eterno significa, nāo a transcendência a toda história (temporal), mas omnipresença, transhistória e portanto imutabilidade em sua forma em toda a sua extensão da história, eu retomarei palavra por palavra da expressão de Freud e dirci: a ideologia é eterna, como o inconsciente. E acrescento que essa aproximação me parece teoricamente justificada pelo fato de que a eternidade do inconsciente não deixa de ter relação com a eternidade da ideologia em geral". ${ }^{9}$

Percebemos aí a questão que é retomada no interior da teoria de Pêcheux (1975). Mas, ainda, é necessário avançarmos nas teses althusserianas para melhor compreendermos a categoria de sujeito que delas decorre e que vai influenciar a teoria de Pêcheux (1975).

9 p. 85 
Uma das teses levantadas por Althusser ${ }^{10}$ é a de que a ideologia representa a relação imaginária dos indivíduos com suas condições reais de existência, ou seja, que o sujeito se institui pela representação da relação imaginária com suas condições reais de existência. O que justifica sua afirmação quando diz que, na ideologia,

'os homens de fato expressam, não a relação entre eles e suas condições de existência, mas o modo como eles vivenciam a relação entre eles e suas condições de existência: isso pressupõe tanto uma relação real quanto uma 'relação imaginária', 'vivida'. (...) $\mathrm{Na}$ ideologia, a relação real é inevitavelmente investida na relação imaginária ${ }^{\text {"I }}$

Essa tese é importante para a questão da articulação entre ideologia e inconsciente. Althusser (1970) sugere que "a ideologia 'age' ou 'funciona' de tal forma que ela 'recruta' sujeitos dentre os indivíduos (ela recruta a todos), ou 'transforma' os indivíduos em sujeitos (ela os transforma a todos) através dessa operação muita precisa que chamamos de interpelação, que pode ser entendida como o tipo mais banal de interpelação policial (ou não) cotidiana: 'ei, você aí!'” (p.96). Essa teoria da ideologia apresenta um quebra-cabeça, pois se o indivíduo humano ainda não é um sujeito, como reconhece e responde ao "chamamento" que faz dele um sujeito? Ciente disso, o autor afirma que somos "sempre-já-sujeitos" mesmo antes do nosso nascimento, pois a nossa chegada já foi preparada, e respalda-se no fato de Freud já ter demonstrado que o bebê tem um lugar no desejo da mãe antes de nascer:

"Que um indivíduo seja sempre/já sujeito, antes mesmo de nascer, é no entanto a mais simples realidade, acessível a qualquer um, sem nenhum paradoxo. Que os indivíduos sejam sempre 'abstratos' em relação aos sujeitos que são desde sempre, Freud já o demonstrou, assinalando simplesmente o ritual ideológico que envolve a espera de um 'nascimento', este 'feliz acontecimento'. (...) isto, prosaicamente, quer dizer que as formas

10 1970, p. 85)

11 Althusser, 1969, p. 233-234, apud Eagleton, 1996, p. 214). 
de ideologia familiar/paternal/maternal/conjugal/fraternal, que constituem a espera do nascimento da criança, lhe conferem antecipadamente uma série de características: ela terá o nome de seu pai, terá portanto uma identidade, e será insubstituivel. Antes de nascer a criança é portanto sujeito, determinada a sê-lo através de e na configuração familiar específica na qual ela é 'esperada' após ter sido concebida". ${ }^{2}$

Mas, se isso é verdade, por que o autor, depois dessa explicação, continua insistindo no ponto central do "momento" da interpelação?

A tese acima mencionada tem como base o ensaio intitulado "O Estádio do Espelho como Formador da Função do Eu", em que Lacan (1949) trata do momento de jubilatório desconhecimento da criança com relação a seu estado afetivo quando confronta-se com sua própria imagem no espelho, ou seja, momento em que a criança percebe a própria imagem e sua diferenciação $\mathrm{em}$ relação ao mundo externo, através da figura do outro, pois nessa condição imaginária não se estabeleceu nenhuma distinção entre o real, entre o sujeito c o objeto. Por isso, o bebê se identifica com sua imagem dentro e diante do espelho ao mesmo tempo.

Olhando dessa perspectiva, o sujeito humano, para Althusser, transcende seu verdadeiro estado de difusão ou descentração e encontra uma imagem de si mesmo (eu imaginário que para Lacan implica uma alienação do sujeito), refletida no "espelho" de um discurso ideologicamente dominante. Assim, a ideologia ć constitutiva do sujeito. Do ponto de vista althusseriano, há fusão do conceito de espelho (estrutura narcísica) com o de ideologia. Ele afirma que:

"a estrutura de toda ideologia, ao interpelar os indivíduos enquanto sujeitos em nome de um Sujeito Único e universal é especular, isto é, funciona como espelho, e duplamente especular: este desdobramento especular é constitutivo da ideologia e assegura o seu funcionamento". ${ }^{3}$

Mais adiante, o autor diz que a estrutura especular duplicada da ideologia garante ao mesmo tempo a interpelação dos "indivíduos" como sujeitos; sua submissão ao Sujeito; o reconhecimento mútuo entre sujeitos e o Sujeito, e entre os próprios sujeitos, e finalmente o reconhecimento de cada sujeito por si mesmo; e 
a garantia absoluta de que tudo está bem assim, e sob a condição de que se os sujeitos reconhecerem o que são e se conduzirem de acordo tudo irá bem: 'assim seja' (p.102-3).

O que aqui se apresenta como problema é que Althusser toma como base somente a primeira forma organizada do processo de constituição subjetiva proposta por Lacan que é o "estádio do espelho". E com isso ele faz intervir só a ordem imaginária e deixa de lado a ordem simbólica, que mediatiza a relação do imaginário com o real. O sujeito lacaniano, "como um todo", pertence à ordem simbólica e também à ordem imaginária, pois é visto como um efeito clivado, faltoso e desejante do inconsciente. Assim, a teoria de Althusser parece resultar de leituras parciais dos textos de Lacan, pois a teoria da ideologia envolve ao menos dois erros cruciais, o que não surpreende dada a obscuridade sibilina desse último, como assinala Eagleton:

"Para começar, o sujeito imaginário de Althusser corresponde, na verdade, ao $e u[m o i]$ lacaniano, que é, para a teoria psicanalítica, meramente a ponta do iceberg do EU [je]. É o eu para Lacan, que se constitui no imaginário como uma entidade unificada; o sujeito 'como um todo' 'é um efeito clivado, faltoso, e desejante do inconsciente que, para Lacan, pertence ao 'simbólico' e também a ordem imaginária. O resultado desse erro de leitura, assim, é tornar o sujeito de Althusser bem mais estável e coerente que o de Lacan, já que o eu 'arrumadinho' faz às vezes, aqui, do desalinhado inconsciente. Para Lacan, a dimensão imaginária de nosso ser é vazada e atravessada pelo descjo insaciável, o que sugere um sujeito bem mais volátil e turbulento que as entidades serenamente centradas em Althusser". ${ }^{4}$

Quais as implicações políticas dessa leitura que expulsa o desejo do sujeito? Um certo pessimismo político é próprio dessa representação. Em primeiro lugar, nas palavras de Eagleton (1996), "expulsar o desejo do sujeito é emudecer seu clamor potencialmente rebelde, ignorando que só de maneira ambígua e precária ele pode atingir o lugar que lhe é destinado na ordem social" (p. 216).

Em segundo lugar, correspondente leitura, diz respeito à interpretação, feita por Althusser, do "grande" Sujeito, ao lado do sujeito "pequeno" ou individual. Com relação à interpelação dos indivíduos como sujeitos, ao lado do sujei- 
to "pequeno" individual, Althusser formula o conceito de "Grande sujeito", constituído pelos significantes ideológicos dominantes com os quais o indivíduo se identifica. Esse "Grande sujeito", na leitura de Althusser, é equivalente ao supereu freudiano pelo poder censor que nos mantém obedientes, em lugares determinados. Esse é um dos aspectos da teoria freudiana que perde a ênfase do decorrer da obra de Lacan.

Ressalto, entretanto, que, ao fazer distinção entre "bons sujeitos" e "maus sujeitos", Althusser deixa escapar que nem sempre o "chamamento" do sujeito ao "grande" Sujeito é bem sucedido, pois, como ele próprio afirma

"envoltos neste quádruplo sistema de interpelação, de submissão ao Sujeito, de reconhecimento universal e de garantia absoluta, os sujeitos 'caminham', eles 'caminham por si mesmo' na imensa maioria dos casos, com exceção dos 'maus sujeitos' que provocam a intervenção de um ou outro setor do aparelho (repressivo) do Estado. Mas a imensa maioria dos (bons) sujeitos caminha 'por si', isto é, entregues à ideologia (cujas formas concretas se realizam nos Aparelhos Ideológicos do Estado"). ${ }^{15}$

Ao admitir a existência dos "maus sujeitos", Althusser admite a possibilidade de falha do assujeitamento, ou seja, admite a possibilidade de o sujeito resistir ao "grande" Sujeito. Isso significa que o modelo que está por trás da tese da sujeição, isto é, a sujeição do $e u$ ao supereu freudiano, poder censor que nos mantém obedientes, em lugares determinados, não funciona sempre, pois na teoria freudiana o $e u$ rebela-se contra o seu senhor imperioso quando suas exigências tornam-se por demais insuportáveis.

\section{Lacan: o sujeito e o Outro}

Embora a categoria do grande Outro não apareça em Freud, o seu reconhecimento já está presente na sua teoria, na dupla alteridade: tanto na figura do outro semelhante quanto na figura do outro que não é semelhante, mas que o remete a "outra pessoa histórica e inesquecível", como podemos ver na referência feita ao ataque histérico, na carta 52 a Fliess: 
"Todos os ataques de tonteiras e acessos de choro visam a uma outra pessoa - mas, basicamente, visam àquela outra pessoa préhistórica e inesquecível, que jamais é igualada por ninguém".16

Lacan, por sua vez, distingue o "pequeno" outro, cuja dimensão envolve o lugar e a função daqueles em relação aos quais se formam o desejo da criança: pai, mãe, irmãos e irmãs, do "grande" Outro, cuja noção é introduzida no Seminário II como aquele que não é semelhante, ao contrário, é enigmático e situa-se como lugar, detendo as chaves de todas as significações inacessíveis ao sujeito que "se parece servo da linguagem; ele é o mais ainda de um discurso em cujo movimento universal seu lugar já está inscrito desde o seu nascimento, ainda que sob a forma de seu nome próprio". ${ }^{17}$

Essa dupla dimensão da alteridade pode nos levar a pensar que o papel do "grande" Sujeito althusseriano é o mesmo desempenhado pelo "grande" Outro lacaniano. Como assinalei, a noção de "grande" Outro, opondo-se a noção de "pequeno" outro, não é semelhante. Apesar de, na visão de Lacan, o inconsciente ser um campo elusivo e traiçoeiro, em que nada fica propriamente no lugar e as relações entre o inconsciente e o sujeito individual serem mais frágeis do que o modelo postulado por Althusser, na formulação lacaniana citada acima, é possível perceber a idéia de um condicionamento do sujeito pelo Outro. Isso nos leva a ver o motivo pelo qual Pêcheux (1975) aproxima Lacan e Althusser e postula a necessidade de articular ideologia e inconsciente.

Dito isto, como se dá a noção de sujeito na obra de Lacan? No Seminário $\mathrm{XI}$, ele apresenta quatro conceitos fundamentais: inconsciente como sujeito, inconsciente como repetição, inconsciente como transferência e inconsciente como pulsão.

No prefácio à edição em língua inglesa do Seminário XI, escrito em 1976, encontra-se a seguinte passagem: "Quando o espaço de um lapso não porta mais qualquer significado (ou interpretação), só então se pode estar certo de estar no inconsciente. Sabe-se" (apud Miller,1995, p. 22). "É isso!", dito quando ocorre um lapso ou uma falha. $O$ inconsciente é apresentado como uma modalidade do nada e ao mesmo tempo uma modalidade do ser. É a isso que Lacan vai chamar de sujeito, sujeito que não tem substância, que é um tropeço, já que algo não se encaixa, mas se expande para preencher o próprio desejo, como assinala Miller. ${ }^{18}$ 
Um pouco diferente do inconsciente apresentado por Freud em a Interpretação dos Sonhos, em Psicopatologia da vida cotidiana, em Chistes e sua relação com o inconsciente, o inconsciente em Lacan é um tropeço, uma falha, desejo, mas também é repetição, pois apresenta uma cadeia ou rede de significantes que sempre diz o mesmo, que está ligado ao real, que não engana, que volta sempre ao mesmo lugar para o sujeito, mas que o sujeito não encontra. $O$ inconsciente também é transferência, apresentada como o engano fundamental do inconsciente e definida como "atualização da realidade do inconsciente": realidade que é sempre ambígua e ilusória, que ilude e engana. E, por último, o inconsciente também é pulsão, vontade que o sujeito não pode evitar e nem deter em si mesmo.

Esses quatros conceitos articulados nos mostram que, quando Lacan afirma que o inconsciente é estruturado como uma linguagem, aponta para um resto para o qual forja o termo alíngua 19 "numa tentativa de nomear justamente aquilo que se furta à univocidade inerente a qualquer nomeação, uma vez que se trata de apontar para o registro que, em toda língua, consagra-a ao equívoco. É nesse sentido que se diz que o sujeito da Psicanálise é assujeitado ao efeito da linguagem, mas subvertido pelos sistemas significantes, ou seja, ele nasce como significante e, por isso,

"nasce dividido. O sujeito é esse surgimento que, justo antes, como sujeito não era nada, mas que, apenas aparecido, se coagula em significante". ${ }^{20}$

A constituição do sujeito pelo significante se faz pela relação circular e se descreve por duas operações fundamentais denominadas alienação e separação. É tentando definir a alienação que Lacan (1964) aponta para a necessidade dos conceitos do sujeito e do Outro, definindo este como "o lugar em que se situa a cadeia significante que comanda tudo e que vai poder presentificar-se do sujeito" (193-4). Entretanto, ele coloca uma outra questão: o sujeito não se define apenas na cadeia significante, mas também no nível das puisões, em termos de seu gozo em relação ao Outro, ocorrendo, portanto, a separação.

$\mathrm{Na}$ estrutura lógica da alienação e separação, Lacan refere-se às operações da teoria dos conjuntos "união" e "interseção". No nível da alienação, temos a seguinte representação:

19 Ver as consideraçōes feitas MILNER, Jean-Claude. em "O amor da língua".

20 Lacan, 1964, p. 188 


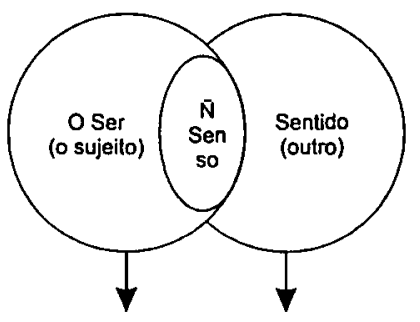

$\left(\mathbf{S}_{1}\right)$

$\left(S_{2}\right)$

Nesse nível, temos dois conjuntos: o conjunto do Outro e o conjunto do ser, transformado em sujeito pelo Outro, transformado pela linguagem. No meio, o não-senso e, do lado direito, o sentido (200). Esses dois termos de onde derivam o não-sentido e o sentido são termos da cadeia significante.

No nível da separação, por seu turno, a representação se dá seguinte forma:

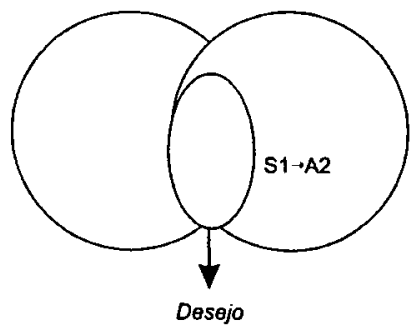

Explicando a separação, introduzida por Lacan no Seminário XI, Soler (1995:62) salienta que esta "supõe uma vontade de sair, uma vontade de saber o que se é para além daquilo que o Outro possa dizer, para além daquilo inscrito no Outro". A condição que torna possível a separação é a dimensão do desejo, aquilo que falta na fala, é metonímia. Portanto, o Outro da alienação, cheio de significantes, não é o Outro da separação, a que falta alguma coisa impossível de se capturar.

Finalmente, podemos falar sobre a estrutura significante de que fala Lacan e que remete ao Nó Borromeano como forma de articulação entre os três registros: Real, Simbólico e Imaginário.

Em torno dessa estrutura e desse Nó, podemos pensar o desenvolvimento da noção de sujeito, acompanhado o deslocamento da teorização do imaginário, para o simbólico e, por fim, para o real. O Nó nos mostra que nenhum dos registros pode ser pensado sem relação um com os outros. Vejamos: 


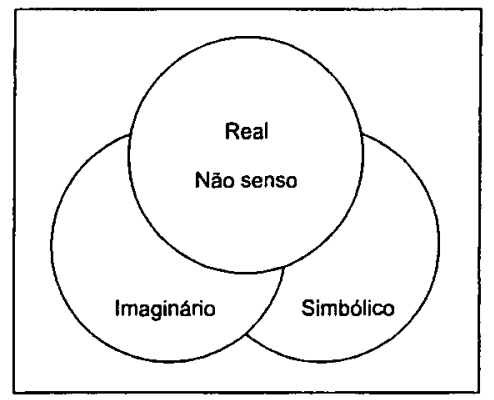

Nó Borromeano

Esses três registros que compõem o Nó parecem ter aparecidos em momentos distintos. No primeiro, o registro do imaginário é privilegiado no artigo intitulado "Estádio do Espelho como Formador da Função do Eu".

No segundo, o simbólico passa a ocupar lugar principal, a partir do artigo "Função e Campo da Palavra e da Palavra em Psicanálise", chegando ao ápice no Seminário sobre a Carta Roubada, em que Lacan expõe a sua teoria do significante, e mostra que a ordem do significante é constituinte do sujeito. Nesse momento, o sujeito aparece como sujeito do significante preso ao eu imaginário, lugar do desconhecimento, e assujeitado à estrutura, sem resto.

Por último, o deslocamento da ênfase do simbólico começa a acontecer com o Seminário de 1958-1959, intitulado Le désir et son interpretation, no qual Lacan chega a conclusão que o Outro, tido como lugar da verdade, não contém o significante que garantiria essa verdade, já que ele é furado, não todo, e o simbólico não se totaliza. Lacan radicaliza a noção de sujeito, empurrando-o para fora da estrutura, no Seminário de 1959-1960, A Ética da Psicanálise, mas é no Seminário XI de 1964 que o registro do Real (que subsiste a toda simbolização, o impossível de simbolizar, o que resta sempre) e a teoria das pulsões ganham o maior destaque na teoria lacaniana.

Entretanto, não podemos pensar esses registros isoladamente. $\mathrm{O}$ nó Barromeano consiste na propriedade de ao se desfazer um dos elos os outros liberarem, como assinala Leite. ${ }^{21} \mathrm{Na}$ mesma página, a autora comenta ainda que a "estrutura consiste, pois, no entrelaçamento dos três registros, pelo Sintoma, dando o lugar ao sujeito". Acrescenta ainda que a "inclusão do sujeito na estrutura, operada no campo discursivo da Psicanálise, realiza a inclusão do Real na estrutura do sujeito, dado que a estrutura é Real e concebida como imperativa e necessária para dar lugar ao sujeito". 


\section{Pêcheux: a causa daquilo que falha ou...}

Após incursão em Althusser e Lacan, retomo o ponto que originou essa discussão. Quando Pêcheux (1975) tenta articular as estruturas funcionamentos: ideologia e inconsciente, apesar de o sujeito, por ele, definido transcender o caráter egóico do sujeito Althusseriano, que está preso ao registro do imaginário $\left(1^{\circ}\right.$ momento de Lacan), ele (sujeito) é remetido ao registro do simbólico $\left(2^{\circ}\right.$ momento de Lacan) e não ao registro do real ( $3^{\circ}$ momento de Lacan em que o sujeito é o da pulsão, do desejo, resultando de uma eterna construção).

Assim, em Pêcheux (1975), o caráter inapreensível desse "Outro", que resulta do fato de o simbólico não se totalizar, o que é mostrado pela noção de real ao longo da obra de Lacan, não está enfatizado. Em outras palavras, faz-se um apelo à Psicanálise, desconsiderando o fato de haver a terceira ordem, a ordem do real, que é impossível de simbolizar, que é o que resta sempre e a partir do qual o desejo começa operar.

Isto teve conseqüências importantes para a teoria, pois o próprio autor, reconhece que algo falhou na relação com a Psicanálise. E no anexo 3, intitulado "Só há causa daquilo que falha ou o inverno político francês: início de uma retificação", Pêcheux (1979) questiona toda a elaboração, principalmente no que diz respeito à maneira que se encontram articulados o recalque inconsciente, o assujeitamento ideológico e os funcionamentos discursivos:

\footnotetext{
"Tudo se passa, em Les Vérités de la Palice, ${ }^{22}$ como se o que foi dito do sujeito se confundisse tendencialmente com o que foi posto ao ego como "forma-sujeito" da ideologia jurídica, a ponto de que o funcionalismo, expulso politicamente pela porta, pudesse, apesar de todas as denegações, ter voltado a tambolirar pela janela psicanálitica, sob a forma de uma espécie de gênese do ego; à força de levar exageradamente a sério as ilusōes do poder unificador da consciência". 23
}

O autor insiste na autocritica e responde ao possível leitor, que se sentir surpreso com as críticas do anexo, da seguinte forma:

22 Tradução brasileira: "Semântica e Discurso: uma crítica à afirmação do óbvio".

23 p. 299 
"não se pode deixar jamais um erro dormir impunemente em paz, pois esse será um meio seguro para que ele perdure; é preciso discernir o que falha não por pretender com isso se amparar definitivamente o verdadeiro(!), mas para tențar avançar tanto quanto se possa em direção à justiça" ${ }^{24}$

Enfim, o anexo 3 nos mostra claramente um téorico que rompe com o que escreveu em 1975, e que, após considerações que apontam para um novo caminho, despede-se traçando "um novo inverno político", no qual "não há dominação sem resistência: o primado da luta de classes, que significa que é preciso 'ousar se revoltar" (cf. p.304), o que nos faz lembrar dos "maus sujeitos", de Althusser; e, no qual, "ninguém pode pensar do lugar de quem quer que seja: primado prático do inconsciente, que significa que é preciso 'ousar pensar por si mesmo"" (cf. p.304), o que nos remete ao registro do real e à vontade e o desejo do sujeito de sair do Outro, postulados por Lacan.

\section{Pêcheux: estrutura e acontecimento...}

Pêcheux (1983b) revê o tratamento que vinha dando a alguns dos seus postulados teóricos, chamando atenção para o estatuto das discursividades que trabalham um acontecimento (ponto de encontro entre uma atualidade e uma memória), entrecruzando proposições de aparência logicamente estável e formulações irremediavelmente equívocas (materialidades léxico-sintáticas opacas que, imersas em uma rede de relações implícitas, funcionam sob diferentes registros discursivos, e com uma estabilidade lógica variável).

Conforme o autor, nos espaços discursivos designados como "logicamente estáveis", tais como os administrativos (jurídico, econômico e político), supõe-se que todo falante (sujeito pragmático) sabe o que diz, pois todo enunciado produzido nesses espaços reflete propriedades estruturais independentes de sua enunciação. Segundo ele, o que unifica, na aparência, esses espaços discursivos é uma série de evidências lógico-práticas em que um mesmo objeto não pode estar em duas localizações diferentes; não pode ter a ver com a propriedade $\mathrm{P}$ e a propriedade não-P, ao mesmo tempo; e um mesmo acontecimento não pode acontecer e não acontecer (p.31).

Assim, nos espaços discursivos "logicamente estáveis", "tudo se passa como se, face a essa falsa-aparência de um real natural-social-histórico homogênco co- 
SILVA, M. da C. F. A relação do materialismo histórico...

berto por uma rede de proposições lógicas, nenhuma pessoa tivesse o poder de escapar totalmente, mesmo, e talvez sobretudo, aqueles que se acreditam 'não simplórios': como se esta adesão de conjunto devesse, por imperiosas razões, vir a se realizar de um modo ou de outro" (p. 32), ou seja, como se as pessoas nunca pudessem subverter e nunca pudessem pensar por si mesmas, assujeitando-se sempre a uma estrutura sem resto e sem falhas.

Acontece, porém, que esta homogeneidade lógica é aparente. Nesse sentido, o sujeito pragmático, que somos todos nós, ganha, importância na teoria de Pêcheux (1983b). Para ele, nós, 'simples particulares', face às diversas urgências de nossas vidas, somos marcados pela multiplicidade de pequenos sistemas lógicos portáteis que vão desde a gestão cotidiana da existência até as 'grandes decisões' de vida social e afetiva, passando por todo o contexto sócio-técnico dos 'aparelhos doméstico'. E nos espaços de necessidade equívoca, é possível colocarmos em jogo uma bipolarização lógica das preposiçōes enunciáveis em todo tipo de nossas conversas, cobrindo regiōes heterogêneas do real.

Portanto, não adianta negar nem essa necessidade (desejo) de aparência, veículo de disjunções e categorizações lógicas, nem que esta necessidade de fronteiras coincide com a construção de laços de dependência face às 'coisas-a-saber', que representam tudo o que arrisca faltar à felicidade do 'sujeito pragmático' e que são tidas como reservas de conhecimento acumuladas (conhecimentos a gerir e a transmitir socialmente), aliadas a um outro tipo de saber que não é reduzido à ordem das "coisas-a-saber" ou a um tecido de tais coisas, mas que diz respeito a um real impiedoso, um conhecimento "constitutivamente estranho à univocidade lógica (...) que não se transmite, não se aprende, não se ensina, $e$ que, no entanto, existe produzindo efeitos". ${ }^{25}$

Com base nessas considerações, Pêcheux propõe um projeto de aproximação das práticas de "análise da linguagem ordinária" e das práticas de "leitura" de arranjos discurvos-textuais (oriundas de abordagens estruturalistas), afirmando que essa aproximação teórica e de procedimentos engaja concretamente maneiras de trabalhar sobre as materialidades discursivas, implicadas em rituais ideológicos, nos discursos filosóficos, em enunciados políticos, nas formas culturais e estéticas, através de suas relações com o cotidiano, com o ordinário do sentido. Mas salienta que esse projeto tem que ficar distanciado de qualquer ciência régia (quer se trate de positivismos ou de ontologias marxistas) para dar certo, além de ter que obedecer a algumas exigências:

A primeira exigência diz respeito ao primado dos gestos de descrição das materialidades discursivas, no qual descrever supõe o reconhecimento de um real específico sobre o qual a descrição se instalada: o real da língua, equivoca e constitutivamente heterogênea. A língua, assim considerada, é atravessada "por uma 
divisão discursiva entre dois espaços: o da manipulação de significações estabilizadas, normatizadas por uma higiene pedagógica do pensamento, e o de transformações do sentido, escapando a qualquer norma estabelecida a priori, de um trabalho do sentido sobre o sentido, tomados no relançar indefinido das interpretações. ${ }^{26}$

A segunda exigência é consequiência do primado dos gestos de descrição das materialidades discursivas, no qual toda descrição está intrinsecamente exposta ao equívoco da língua. E por isto todo enunciado é suscetível de tornar-se outro, diferente de si mesmo, deslocar-se discursivamente de seu sentido para derivar para outro, desde que não haja proibição explícita de interpretação própria ao logicamente estável. Em outras palavras, toda descrição de um enunciado ou de uma seqüência coloca em jogo o discurso-outro que, enquanto espaço virtual de leitura ou presença virtual na materialidade descritível, marca no interior desta materialidade, a insistência do outro como lei do espaço e de memória histórica, como o próprio princípio do real sócio histórico.

A terceira exigência, por sua vez, fecha a questão do tratamento dado à discursividade como estrutura e acontecimento. $O$ autor afirma que todo discurso, pela sua existência, marca a possibilidade de uma desestruturação-reestruturação de redes de memória e de trajetos sociais. E que "através de descrições regulares de montagens discursivas se pode detectar os momentos de interpretações enquanto atos que surgem como tomadas de posição, reconhecidas como efeitos de identificação assumidas e não negadas". 27

\section{Considerações finais... mas não últimas}

Tentei nesse artigo refletir e, também, compreender a relação do Materialismo Histórico com a Psicanálise e suas implicações para a AD. Por isso fiz uma incursão, primeiramente, em Pêcheux, para daí retornar a Althusser e Lacan para tentar mostrar o momento de ruptura de Pêcheux (1989) com o que havia formulado em Les Vérités de la Palice, em 1975; e, finalmente, falar sobre o Pêchex de Estrutura ou acontecimento?.

Vimos que os "bons" sujeitos de Althusser não escapam ao chamamento do assujeitamento, mas vimos também que $o$ assujeitamento pode falhar, pois existem os "maus" sujeitos subvertendo. Além disso, vimos que o sujeito de Lacan é assujeitado aos efeitos da linguagem, mas é subvertido pelos sistemas significantes, ou seja, o sujeito aliena-se, mas também separe-se, está na estrutura, mas também 
SILVA, M. da C. F. A relaçāo do materialismo histórico...

fora dela. E, por fim, que, ao se dar conta disso, Pêcheux (1983b) lança mão de um sujeito pragmático que, dividido, clivado e assujeitado, ousa revoltar-se e tentar pensar por si mesmo.

\section{REFERÊNCIAS}

ALTHUSSER, L. (1964). "Freud e Lacan", In: Freud e Lacan, Marx e Freud. Rio de Janeiro: Graal, 1984. . (1976). "Marx e Freud". In: Freud e Lacan, Marx e Freud. Rio de Janeiro: Graal, 1984. (1970). Aparelhos Ideológicos do Estado. Rio de Janeiro: Graal, 1983. (1972). Elementos de Alttocrítica. Rio de Janeiro: Graal, 1978.

EVANGELISTA, W. J. "Introdução : Althusser e a Psicanálise". In: Freud e Lacan, Marx e Freud. Rio de Janeiro: Graal, 1984.

EAGLETON, T. (1996). "A ideologia e suas vicissitudes no marxismo ocidental". In: ZIZEK, Slavoy. (org.). Um mapa da ideologia. Rio de Janciro: Contraponto, 1996.

LACAN, J. Escritos. (1966). São Paulo: Perspectiva, 1978.

LACAN, J. (1975). Seminário I (1953-1954) os escritos técnicos de Freud. Rio de Janeiro: Zahar, 1979).

(1975). Seminário II (1954-1955): o eu na teoria de Freude na Técnica da psicanálise.

Rio de Janeiro: (Zahar), 1975. Séminaire (1958-1959). Le désir et son interprétation. Paris XI: I.SI (s/d). . (1973a). Seminário VII ( 1959-1960) A Ética da psicanálise. Rio de Janeiro Zahar, 1991. (1973b) O seminário XI: os quatro conceitos fundamentais da psicanálise (1964). Rio de Janeiro: Zanar, 1995.

"O estádio do Espelho como formador da função do eu (1949)". In: ZIZEK, Slavoy. (org.). Um mapa da ideologia. Rio de Janeiro: Contraponto, 1996.

LEITE, N. Psicanálise e Análise do Discurso: o acontecimento na Estrutura. Rio de Janciro: Campo Matêmico, 1994.

MILLER, J. A. (1995). "Contextos e conceitos". In: FELDSTEIN, R. et alii (orgs.). Para Ler o Seminário /I de Lacan. Rio de Janeiro: Jorge Zahar Editor, 1997.

.PÊCHEUX. M. (1975). Semântica e discurso: uma critica à afirmação do óbvio. Campinas: Editora da UNICAMP, 1995.

. (1979). "Só há causa daquilo que falha ou o inverno político francês: início de uma retificação". In: (1975b). Semântica e discurso: uma crítica à afirmação do óbvio. Campinas: Editora da UNICAMP, 1995.

. (1983a). "A Análise do Discurso: três épocas". In: GADET, F e HAK, T (orgs.) Por uma análise automática do discurso: uma introduf̧ão à obra de Pêcheux. Campinas: Editora da 
SILVA, M. da C. F. A relação do materialismo histórico...

UNICAMP, 1990.

. (1983b). O discurso: estrutura ou acontecimento?. São Paulo: Pontes, 1990.

RINALDI, D. (1996). A ética da diferença: um debate sobre psicanálise antropológica. Rio de Janeiro: Ed. UERJ: Zahar.

SILVA, M. da C. F. (1999). Discursos de gênero em revistas femininas: o caso CLAUDIA. Dissertação de mestrado. UNICAMP: IEL.

SOLER, C. (1995). "O sujeito e o Outro II". In: In: FELDSTEIN, R. et alii (orgs.). Para Ler o Seminário I/ de Lacan. Rio de Janeiro: Jorge Zahar Editor, 1997. 